\title{
Evolutionary ontology and biofile transformation of culture
}

\section{Ontologia evolutiva e transformação biofílica da cultura}

\section{Ontología evolutiva y transformación biofílica de la cultura}

\author{
Josef $\check{S}$ majs ${ }^{1}$
}

\begin{abstract}
The author claims that two large transformations of the human adaptive strategy have occurred in the course of our species' history: first, the self-preservation modification at the beginning of the anatomically modern humans' origination; second, the spiritual abandonment of live nature two millennia before the end of the Neolithic culture. Moreover the third transformation, the shift from the predatory spiritual paradigm to the biofile paradigm, has to be undergone today. This transformation is specified with respect to the natural sciences and education system.
\end{abstract}

Keywords: Evolutionary ontology. Nature. Culture. Predatory spiritual paradigm. Biofile spiritual paradigm.

Resumo: O autor afirma que no curso da história da nossa espécie ocorreram duas grandes transformações na estratégia adaptativa humana: primeiro, a modificação da autopreservação no início da origem anatomicamente moderna dos humanos; segundo, o abandono espiritual da natureza viva dois milênios antes do fim da cultura neolítica. E a terceira transformação, esta a ser efetivada hoje, corresponde à mudança do paradigma espiritual predatório para o paradigma biofílico. Essa transformação é especificamente relativa às ciências naturais e ao sistema educacional.

Palavras-chave: Ontologia evolutiva. Natureza. Cultura. Paradigma espiritual predatório. Paradigma espiritual biofílico.

Resumen: El autor afirma que en el curso de la historia de nuestra especie ocurrieron dos grandes transformaciones en la estrategia adaptativa humana: primero, al inicio del origen anatómico moderno de los humanos, la modificación de la autopreservación; segundo, el abandono espiritual de la naturaleza viva dos milenios antes del fin de la cultura neolítica. Y la tercera transformación, esta en transcurso hoy, corresponde al cambio del paradigma espiritual predatorio hacia el paradigma biofílico. Esta transformación se refiere específicamente a las ciencias naturales y al sistema educativo.

Palabras-clave: Ontología evolutiva. Naturaleza. Cultura. Paradigma espiritual depredador. Paradigma espiritual biofílico

\footnotetext{
${ }^{1}$ Masarykova univerzita (Brno, Czech Republic).

author_biographical_data
}

Civitas, Porto Alegre, v. 19, n. 2, p. 409-422, May-Aug. 2019

Este artigo está licenciado sob forma de uma licença Creative Commons Atribuição 4.0 Internacional, que permite uso irrestrito, distribuição e reprodução em qualquer meio, desde que a publicação original seja corretamente citada. https://creativecommons.org/licenses/by/4.0/deed.pt_BR 
Continuously arising human, social and political conflicts that accompany the globalizing Culture (civilization) have occupied the minds of theoreticians, politicians and mainstream media. Frequent conflicts at all levels of the cultural system have been turning attention away from the deep existential dependence of the Culture upon Nature, though. Yet the Roman Club unequivocally described the limits placed by the Nature on the long-term development of the Culture as the limits of growth some fifty years ago (Meadows, 1972). Even though this has hinted at the borders of the Culture's expansion, no deeper ontological understanding of the Culture has been achieved. Contemporary thinking has repeatedly returned into the same track of anthropological deliberations that have been successfully exploited by the everyday politics. It is avoiding the truth since finding the truth requires not only a system-wide but also a historic approach - the evolutionary ontological theory of existence.

\section{Evolutionary ontology: theoretical starting point}

A truthful report on the contemporary situation cannot be based on either a candid approach of common sense or the narrow-minded analyses of the current social sciences. With regard to the hidden character of many relations, we have to reconstruct it from the viewpoint of a sufficiently wide and deep evolutionary-ontological theory. It probably requires us to recognize the philosophical-ontological claim that cultural evolution is not a continuation of the natural evolution. ${ }^{1}$

The Culture, which is a product of a single biological species, must originate from a naturally ordered Earth, it must have a different structure, yet it cannot have its own territorial, material and energy foundation. Therefore, it cannot be as independent, complex and "wise" as Nature. It has to embrace the Earth again, after a temporary diversion, not only with regard to its existence but also with regard to its evolutionary perspective.

Traditional ontology, origins of which are connected with Greek philosophy, had been a general theory of existence. This ontology did not differentiate between the natural and artificial cultural structures, though - it investigated an inanimate natural existence without humans and without the presence of the Culture. It was speculative, and consoling. It preferred, with some exceptions, stability, passivity and reversibility within the understanding of existence. The Greek theory did not know either the linear flow of time or the essence of life and its relationship with inanimate processes. ${ }^{2}$

\footnotetext{
${ }^{1}$ For a different opinion on this see e.g. Latour (2016).

2 Let's note that theoretical understanding of live systems has been complicated. It is well known that Luis Pasteur (1822-1895) had to defend the idea of bacteria presence in the air as late as in the nineteenth century.
} 
Yet evolutionary ontology ${ }^{3}$ stresses the processuality and irreversibility in the concept of natural existence. Terrestrial existence-in line with contemporary science - is understood as a creative evolution that produces structures and orderliness (information). The orderliness of the Earth, a product of natural evolution, may therefore both come into existence and disappear independently from the implications of the laws of mass and energy preservation.

The ontical (physical) conflict between the Culture and the Nature is the substantial issue being underway on the Earth, besides the difference between the two evolutions. The planetary scope of this conflict threatens to exterminate our species, for the first time in our species' history. The natural evolution of the Earth, which may be blind but spontaneously configured to start and develop life, is a continuation of the development of abiotic structures. It does not plunder the Earth; quite to the contrary, it enriches the planet with its biological structures, including the human species.

I would like to note here that the influential author of economic liberalism, F. A. Hayek, who did not differentiate between the cultural and natural evolutions, claimed the following: should evolution optimize social structures, internal structures, and relationships within the system it creates, it must be blind (Hayek, 1973). He would have been undoubtedly right within a culture, which is a direct continuation of nature. The contemporary blind, predator-configured Culture does not evolve towards its optimal structure or towards cooperation with the wider natural biotic evolution. Quite to the contrary, it threatens the human species with extinction.

I also would like to note here that the orientation (setting) of the humanignited evolution of the Culture, which had not been any continuation of the natural evolution from the outset, must have been different from the biofile setting of the natural evolution. Moreover it is this predatory setting, which had certainly been beneficial once, that we must attempt to change to preserve our own species existence. To make sure that this difficult change is essentially possible, let us recall the origination of the spiritual predatory setting (paradigm) of the Culture.

\section{Human genome shaping}

Only two large modifications of the human adaptive strategy have taken place in the course of our species' history: first, the self-preservation modification at the beginning of the anatomically modern human's origination;

\footnotetext{
${ }^{3}$ See e.g. Šmajs (2008a). For the most comprehensive description of the evolutionary ontology concept see the following book published in Czech: Šmajs (2008b).
} 
second, the spiritual abandonment of live nature two millennia before the end of the Neolithic culture. The third (biofile) modification must be performed now to preserve our own species.

The first formative change in the human species evolution was caused by the natural disaster a few million years ago in equatorial East Africa. This resulted in a climate change and an irreversible loss of the natural home (environmental niche) of our hominid ancestors, who had lived in the treetops of the African rainforest. These hominids, adapted to a relatively safe tree mode of life, were forced to live in a bushy savanna after the opening of the Great Rift Valley. Threatened by complete extinction they had to relatively quickly adapt to the new conditions. The previous life in the trees had been something like life in the paradise - it provided sufficient food in the form of fruits, insects and edible sprouts. It had been a natural hideout from terrestrial carnivorous animals, provided undisturbed night rest and so on. ${ }^{4}$

The forced life in the savanna reminds the expulsion from Paradise since it resulted in a more difficult way of acquiring food. Our ancestors were required, for example, to build primitive dwellings on the bare ground and to establish a more sophisticated social organization. It was necessary to master the fast and long-lasting movement on the ground without the use of the front limbs, provide security for the whole troop from predators, discover new kinds and methods of acquiring food and improve communications. Acquiring food of animal origin required completely new hunting strategies, including the use of fire, deception and suitable tools. It seems that most populations of our remote ancestors had died out in that time.

The populations that managed to adapt became a foundation for the new Homo species. The aggressive adaptive strategy, including the proven talent for language communication and cooperation, has gradually become embedded in the human genome. Approximately since this time, we are a species which is biologically predetermined to control its environment and create replacement environmental niches - cultures. ${ }^{5}$

The period of hunting and gathering, a long period when humans were actually parasites on both plants and animals, encompassed most of the anatomically modern humans' history (100-200 thousand years). To this day there are hunters and gatherers who have not been influenced by any direct

\footnotetext{
${ }^{4}$ Naturally, the hominids have preserved all the important somatic pre-adaptations from their life in the branches: small teeth for consuming soft fruits, long fingers, color stereoscopic vision, collective mode of life, etc. They had preserved their "animal-like awareness" of their fundamental biological unity with the Nature.

${ }^{5}$ Compare also Dawkins (1989).
} 
contact with Greek philosophy and science and who have not accepted the predatory spiritual paradigm. They have remained predators but their psyche even today includes both inborn powers in a dynamic balance: an aggressive strategy and a feeling of a close unity with the Nature. ${ }^{6}$

\section{The predatory spiritual paradigm}

The second large adaptive modification, which had paradoxically drawn the Culture away from Nature in the last third of the Neolithic society's existence, was actually an indirect result of the introduction of agriculture at several places on the planet. This change was closely tied to the end of the last Ice Age in the Northern hemisphere, i.e. to the expansion of grassy areas to places glaciers had retreated from.

In comparison to hunting and gathering, general preconditions of which had been encoded in the human genome since the tree-life period of our ancestors, the agricultural technology was probably a more intellectually demanding activity for humans: it presumed not only inborn intelligence, skills and physical force but also a different level of understanding of the Nature. It was sufficiently transparent and therefore it developed human intellectual skills. The almost imperceptible biological development of the humans, proceeding for tens of thousands of years in natural ecosystems, was thus replaced by a much faster cultural development. It had lasted just a few thousand years, though.

The relatively quiet period of the dominant Neolithic technology was unexpectedly followed by different fundamentals of the originally biofileoriented human thinking. This was the period of a great spiritual strife (the so-called "axis period" between approximately 800 to 200 BC - K. Jaspers) when monotheistic religions appeared along with the formative abstractions of the Greek science and philosophy (Jaspers, 1931). Here we can observe a departure from the complex live nature and a tendency towards analyzing inanimate constructs and relationships. New theoretical terms and postulates appeared with regard to this interpretation.

The biological predisposition towards the aggressive adaptive strategy in the human genome was spiritually strengthened by the Culture. A narrow group of scholars from the then cities, liberated from empirical worries, drove gods away from Nature and through a purposefully developed theoretical work discovered terms and ideas which, when expressed by a hypostasis, weakened

\footnotetext{
${ }^{6}$ We can use the still surviving hunters and gatherers as an example just like the native inhabitants of the Americas before European colonization.
} 
and distorted the significance of Nature. This was clearly demonstrated by the Greek philosophy. On the one hand, the Greek philosophy still acknowledged the myth and common sense; it supported a commonly used rationality, especially the single-level mechanical way of reality interpretation. On the other hand, it promoted the idea of identity (uniformity) of thinking and existence-especially under the influence of the Eleates (Parmenides). And it was this identity that Plato and many later thinkers, including the religious ones, understood as the dominance of thinking over existence. These were the two features that established the basis for the predatory spiritual paradigm. Educated people were presented with the ideas of a false pre-understanding of Nature, which had been understood to be a dead material moved by external forces. ${ }^{7}$

Nothing of substantial significance could change in the relationship between the cultural systems and Nature before the end of the Neolithic society, though. People continued to work hard since the processes they could turn against Nature were based only on the force of animals and human proprietary existential forces. The necessity of direct cooperation with the more powerful natural systems controlled their aspiration to resist Nature. ${ }^{8}$

This restriction was broken only by the New-Age Galileo-Newtonian science. Its technological terminology, application of mathematics and causal single-level interpretation of reality were a continuation of the spiritual heritage of the Antiquity. In harmony with Bacon's metaphor it "turned knowledge into power". In conjunction with the Capital, it got materialized in the material culture and the technics and helped to initiate the Industrial Revolution. It assisted with the mechanization of agriculture, transportation, and the military. And the Ancient predatory paradigm has found its climax in the global abiotic consumer culture. It reduces the Nature to forces, material and energy and for the sake of its own short-lived success, it provides all the people with weapons of mass destruction of the planet - namely the worldwide distributed passenger cars.

\section{The biofile self-preservatory transformation}

The acknowledgment of two great turning points in the history of the human adaptive strategy is the reason why I do not attempt any explicit critique of the contemporary form of corporate capitalism. I increasingly consider such

\footnotetext{
${ }^{7}$ Contemporary social sciences, on the other hand, force upon us the false pre-understanding of the Culture, which is understood to be a continuation of the natural evolution of the Nature through different means. They falsely interpret the Culture as an environment, which is fully compatible with humans since it has been created by humans.

${ }^{8}$ The natural humility of a weak human with regard to the Nature, which has been gradually suppressed by the forces of science and technology, will have to be replaced by humility of a different type: a fear that the Culture could irreversibly hurt the fragile Nature.
} 
a critique to be a theoretically little understood problem. ${ }^{9}$ Such a critique might be legitimate from a social point of view but it does not point towards the roots of the problem. It would be unwise to fight for a new and socially more just society and new entrepreneurial morals at the time of a global existential threat to the Culture. The conquest-oriented spirit of the Culture would be preserved. The reversal we need must be deeper; it must be based on a modification of the adaptive strategy of the global Culture as a whole.

I think that the contemporary form of capitalism finds its support in the two layers of the second turning point. The first, deeper and more difficult layer to access consists in the origination of the above-mentioned predatory spiritual paradigm of the Culture. The second, easier layer to access, consists in the contemporary spontaneously arising form of economy, consumption and material culture growth (including the technics).

Socially-political forms of cultural life are actually dependent variables and therefore, contrary to the short-term human effort, they approximately correspond to the spontaneously developing structures of the cultural system. For instance, the feudal conditions in Europe approximately corresponded to the ownership of soil and the vassals bound to this soil, while classic capitalism better corresponded with the culture-created conditions: the ownership of mechanized factories, commodity-monetary relations and hiring the relatively free workers. Therefore the contemporary corporate capitalism is an adequate form of expansion of the predatory-oriented yet uncontrolled evolution of the material-technical foundation of the Culture. The anti-natural orientation and structure of this Culture are hidden (yet this hiding is increasingly more difficult to maintain) behind the high levels of unnecessary personal consumption and the acclaimed idea of human freedom and rights. ${ }^{10}$

If we want to work for the removal of the contemporary form of the unsustainable world capitalism, we have to understand the different weights of the two above-mentioned layers. Their significance is not discussed or voted on in elections. Putting it otherwise: first, without a biofile transformation of the spiritual foundation of the Culture, it is impossible to remove the deep

\footnotetext{
9 This also applies to the successful book by Klein (2008) The shock doctrine: the rise of disaster capitalism.

${ }^{10} \mathrm{I}$ would like to note here that after the victory of capitalism in Europe humankind has had no real possibility to fundamentally change the direction of the cultural evolution. And real socialism, leaving aside its internal problems, was a less successful social form of life under approximately identical material-technical conditions. The predatory-oriented science was united with the similarly oriented government power. It competed with capitalism for higher labor productivity. This could be the reason why the contemporary attempts in new social orders in the countries of Latin America, China and elsewhere show little hope with regards to their long-term survival.
} 
functional link between the technological powers of the reduced-natural sciences with the power of the capital. Second, we cannot break the current dependence of the social form of capitalism on the so far highest-achieved level of the spontaneous development of the abiotic-oriented science, technology and economy (see also Beck, 2008).

Capitalism - in contrast to the previous socio-economic formations has been, from the outset, connected with the New Age predatory setting of the Culture, with the social demand for a production-useful science. There lies both its strength and weakness. Therefore the biofile, i.e. life-protecting spiritual setting of the Culture, could not only be the self-preservatory act of the human species but also the searched for social-political change.

\section{The earth: the system superior to the culture}

While accepting the risk of being misunderstood, I would like to note the following: Since we cannot change the human constitution, which had been shaped a long time ago without our contribution, we have to attempt to change what we can, using wide critical rationality for the purpose of our own species preservation. And this is the currently unsustainable conquest-oriented setting of the Culture.

If the globalized Culture, representing an imagined tumor on the planet, does not want to die, it must submit to the overwhelming force of its wider and more powerful host system -the Earth (Capra, 2002).

I will attempt to outline this difficult self-preservatory transformation, whose change subject is only it the stage of shaping. I think that the determining role in this large cultural transformation must be played by a higher-order theory - the evolutionary ontology. Its most powerful force - the natural science - has become estranged to human interest and puts up resistance to both, humans and the Earth, due to its predatory setting in the contemporary, spontaneously evolving culture. Since it is covertly preset for technological conquest, it plunders the Earth and "does not feel threatened" either by live systems sciences or by the shallow reflection of its function by the uninformed public and the insufficiently exhaustive social sciences.

The against-the-nature oriented technical knowledge, in association with the capital, not only induces the crisis but also successfully hides this crisis through the education system and major media. The contemporary everyday politics and media also care for the pretty image of the application of partial natural sciences on reality. It is therefore paradoxical that with the growing potential role of philosophical ontology within the Culture, philosophy has been pushed out not only from the university education process but also from 
the reflection of culture, criticism of the social application of science and the process of ideological influencing the public by the politics.

Major media present the state-of-the-art products of natural sciences and the technics, namely the problematical advances in conquering the universe, communication technology and artificial intelligence development on the one hand and superficial anthropological analyses of partial health-related and sociocultural problems on the other hand. It is concealed, though, that this very pragmatic interpretation prevents us from seeing the causes and means of dealing with the crisis.

It has already been said that in ancient Greece, where the Culture had still been a local and mostly biofile one, philosophy had already been an ontology. Despite being speculative and consoling, it tried hard to understand the world as a whole. It had been impossible due to the fact that there had been no natural life sciences or awareness of the incipient Culture - the artificial existence evolutionarily oriented against the Nature - at the time. The Greeks could not have had any experience with the application of the spiritual orientation they had established. They could not have anticipated that science, preferentially focused on studying ideal quantities and inanimate structures and relationships, would leave the human species interests behind, ally itself with the material culture and secular power and attack the naturally ordered Earth. Since they did not know what Nature was, they could not have understood the artificial character of the Culture or its wider natural conditionality. They had no idea about the future destruction of the planet's habitability due to the predatoryoriented expansion of the contemporary global culture.

Therefore philosophy, which is mostly to be blamed for this distortion, must be the first to wake up from this dogmatic sleep and demonstrate once again its spirit of criticism and ideological power superior to the sciences and human activity. Its courage to publicly reveal and condemn the suicidal character of the predatory spiritual paradigm could help the partial social sciences, morals and other regulatory bodies, including the law and the politics. Arguments, why it is necessary to overrule the compulsive human need to keep pointlessly modifying the planet must come from the most authoritative theoretical discipline whatsoever. There is no higher authoritative form of rationality that could reliably diagnose and inform the public that it is a crime to damage the Earth and the health of our descendants. ${ }^{11}$

\footnotetext{
${ }^{11}$ Czech poet Viktor Dyk wrote almost a hundred years ago in his poem Země mluví (The earth talks): "How is it possible to perform a bad act with awareness? You could betray yourself. But your descendants? Why did you give up as long as you breathed? What were you afraid of?" (Descriptive translation).
} 
Yes, cultural evolution has to be blind if it wants to adequately structure itself. Therefore the cultural order originated spontaneously at the beginning. It could not have originated from chaos, though, from which the natural order grew. It originated inside an older and more complex natural order and at the expense of this order. With respect to the absolute dominance of the Earth it could have been anti-naturally (both genetically and later also predatorily) oriented for a long time. The contemporary culture has reached the phase, though, when it cannot continue its anti-natural expansion. The Earth is occupied and conquered. The spiritual reversal of the Culture, its cooperation with the Earth - its superior system, therefore, will be a self-preservatory act of the human species.

\section{Science content transformation outline}

Since it is impossible to have a relevant idea about most aspects of the biofile transformation of the Culture before it starts, I will limit my deliberations to two fields (the science and education system content transformation), which are related to the philosophical initiative of the transformation. I will only make three notes with regards to the complicated requirement for the biofile content transformation of the reductionist natural sciences. The scope of this task is beyond the power of any general theory after the two millennia when sciences, churches and the politics have been approving and supporting the plundering of the Earth. This issue must be specifically discussed only in the course of the biofile oriented process of cultural evolution. Natural sciences, successful mostly through their technical applications, will naturally dodge any well-meant reproaches regarding their failure to cognize the Nature in a complex and adequate way and claiming that their reductionism and venality have contributed to the current crisis (Wilson, 1998).

Note One. Nature is a creative subjectivity, it gave birth to everything inanimate and animate, including humans. Humans, biologically preset for an aggressive adaptive strategy, did not receive their cognitive apparatus to cognize the complexity and nuances of the processual arrangement of the natural existence. Humans received their sensory-neuronal equipment for the purpose of their species' survival on a healthy Earth. The obstinate refusal of this elementary fact and presentation to children, students and the public of the incorrect claim that humans cognize the Nature correctly since they can technologically utilize it, results in a lifelong ideological confusion. It is not only the source of contempt for the Earth, the only possible natural home of humankind but also the support for its contemporary plundering. 
Note Two. We certainly know that results of mathematical, physical and technical sciences shall not be judged by mere practicality, usefulness and sales rates of material culture and technical objects. We will not be able to consider logic and the traditionally conceived truth as a sufficient criterion of scientific research correctness; theoretical and practical compatibility between culture's knowledge and products and the modified reality shall be such a criterion. It means that natural sciences will have to strive to comprehend natural existence in a wider and more complex way; their knowledge, designed for practical applications and education should merge with the natural existence without any conflicts.

Note Three. Humanity has been developing natural sciences, preset by the Antique predatory spiritual paradigm, to be able to apply the newly acquired knowledge in both practical and ideological ways. Humanity has developed them in the interest of its anthropocentric pride and feeling of superiority to Nature. Unfortunately, this knowledge has only little contributed to the growth of the innate human humility in front of the independent, creative and evolutionarily highly ordered terrestrial Nature. It is the great philosophical goal of today to transform science from the tool of conquest and humiliation of the Nature, from the medium of power over the Nature into a medium of reverence and admiration for the Earth and its subjectivity and into a user manual for cooperation between the artificial Culture and the Earth (Šmajs, 2016).

I would like to note again here that these evolutionary ontological requirements must be adopted and creatively elaborated by a biofile-oriented science itself. The science in Greece followed common sense, myths and ignorance about the human role within Nature. It established a speculative type of rationality about human superiority. We can be sure that an evolutionarily informed rationality will not support a culture based exclusively on expansion and thoughtless burning of fossil fuels anymore.

\section{Education system content transformation}

I will discuss the outline of the biofile transformation of the contemporary education system in greater detail. When promoting a new biofile image of the world we have to use a different approach as early as at the elementary school instead of teaching the traditional natural-science subjects and their idealized values such as circle, body, mass, force, energy, movement, space and time. I do acknowledge that these values are measurable and that they can be used by both the didactic-practical methods and the mathematical natural sciences applied in the technology field. Yet as a part of strengthening the reverence for 
the Earth we must not avoid the less specific but systematically correct terms that are more adequate to the active Nature.

Teachers must have the courage to teach the generally affirmed truth to make sure that pupils and students realize the fundamental unity between humans and the Earth and also the dangerously growing artificial character of the Culture, which is not compatible with the human organism either somatically nor psychically. It is necessary to teach the pupils that lack of outdoor exertion, abuse of information technology and harmful chemicals in the air, soil and foodstuffs are the major causes of contemporary civilization diseases. They must not be afraid to point out the systematic unity of the planet, the selfregulation system, to describe the Earth as the wildest terrestrial subjectivity, the highest natural value of all. ${ }^{12}$ Revelation of cooperation between animate and inanimate systems - in contrast to the contemporary conflict between the Culture and Nature - could be a model of future cooperation between the biofile culture and the Earth.

Defense of the unique character of the terrestrial nature will require not only some of the traditional school subjects and terminology but also new subjects and terms with evolutionarily-ontological contents. The following should be among the newly taught subjects: Nature (Universe, Earth), Humans, and Culture. New terminology should include e.g. activity, evolution, information (orderliness), cooperation, compatibility, incompatibility, balance, and natural and cultural creativity.

\section{Courage to depart from tradition}

Even though we are, to a large extent, bound by our natural language, code, and terminology which we cannot leave behind, we must give up the exaggerated reverence for both Greek and New-Age authorities. These thinkers had lived at times when humanity was poor, sciences undeveloped and when the Culture damaged the Nature only locally. They searched for paths of fast human growth and economic exploitation of Nature. We have achieved both of these goals today. Therefore we will have to leave behind the NewAge technological pressure on Nature with dignity before the damage gets even more prominent. The consumer technical society irreversibly ravages the Earth yet it does not contribute to human health and happiness as we can see. To the contrary, it damages and frustrates increasing numbers of people in a hidden way.

${ }^{12}$ This issue is discussed in the philosophical concept of the Constitution of the Earth. See Šmajs, J. Ústava Země (in Czech, English, German, Russian and Slovak). Banská Bystrica $<$ ustavazeme.cz>; <earthconstitution.eu/en/>. 
The new assemblies will have to include the traditionally taught subjects (e.g. physics, biology, and chemistry). We have not had any need to criticize the enlightened didactical heritage of our ancestors until recently. Even in the field of natural sciences teaching we could divide the natural existence into independently taught subjects and consider the entity of the Nature to be an object, which is complex, stable and moving yet does not feature any intrinsic activity, balance, and creativity. We could uncritically give precedence not only to the artificial Culture over Nature but specifically to ideas, defined in the period of their reduced interpretation (Spitzer, 2012).

It is no longer possible to trust the New-Age science and philosophy, e.g. the great Descartes. Since he did not know that the Natural existence is an ontically creative activity, he could not have anticipated, when defining the res cogitans a res extensa duality, that both of these seemingly opposite poles of the world (Nature and Humans) belong one to each other, that they are both products of the same natural evolution of the Earth.

Under the weight of empirical evidence, we have to acknowledge that the Earth is characterized by a completely different duality: the deep existential opposition of the older and wider natural evolution and the partial, humanignited anti-natural cultural evolution. We know that humanity can continue the cultural evolution only if it can overcome anthropocentrism and implements a biofile spiritual transformation of its current anti-natural heading with the help of philosophical ontology.

What kind of social-political organization will come out of this is hard to foretell today. Since the contemporary cultural evolution is aimed against the long-term biological interests of humanity, its orientation cannot be left in the hands of either the elected or the non-elected (wealthy) representatives of the contemporary power structures. It seems that only independent and incorruptible experts on the principles of the global existential conflict can defend the interests of our species in this complicated situation, even though this might sound rather intellectually. And since this principle does not consist in the conflicting interests of two or more power groups, as insinuated by the interpretations of contemporary political scientists and major media, but in a rarely unified predatory process used by the technologically most advanced part of humanity to exploit the planet, the rights and subjectivity of the Earth can be represented and defended only by a biofile-competent group of critically thinking intellectuals.

It seems that there are processes running within partial sciences, the arts and educational systems which generate persons with such a globally altruistic focus. The search for and advancement of these persons has been successfully 
prevented by the conquest-oriented spirit of our times: the merciless, sciencesupported competition in plundering the planet. Initiation of the biofile spiritual transformation and growth of the philosophical ontology role within the Culture are the issues of life and death for the contemporary technical civilizations, though.

\section{References}

BECK, Ulrich. World at risk. Cambridge: Polity Press, 2008.

CAPRA, Fritjof. The hidden connections. New Yok: Anchor Books, 2002.

DAWKINS, Richard. The selfish gene. Oxford: University Press 1989.

HAYEK, Friedrich A. Law, legislation and liberty. London: Routleget Kegan Paul Ltd., 2003.

JASPERS, Karl. Die geistige Situation der Zeit. Berlin: Walter De Gruyter, 1931.

KLEIN, Naomi. The shock doctrine: the rise of disaster capitalism. London: Penguin Books, 2008.

LATOUR, Bruno (ed.). Reset modernity! London: MIT Press, 2016.

MEADOWS, Dennis. The limits to growth. New York: Universe Books, 1972.

SPITZER, Manfred. Digitale Demenz. Wie wir uns und unsere Kinder um den Verstand bringen. Munchen: Droemer Velag, 2012

ŠMAJS, Josef. Evolutionary ontology. Reclaiming the value of nature by transforming culture. Amsterdam; New York: Rodopi, 2008a.

ŠMAJS, Josef. Filosofie: obrat k Zemi. Praha: Academia, 2008b.

ŠMAJS, Josef. Fenomén technika. Brno: Doplněk, 2016.

WILSON, Edward O. Consilience. The unity of knowledge. New York: Alfred A. Knopf, 1998.

Received at: 29 Sept. 2018

Approved at: 15 Jan. 2019

Published at: July 2019

Corresponding author:

Josef Smajs

Zerotinovo nam. 9

Brno, Czech Republic

JOSEF ŠMAJS < Josef.Smajs@econ.muni.cz>

Masaryk University (Brno, Czech Republic)

Orcid: https://orcid.org/0000-0002-2204-4595 